\title{
Pelatihan Identifikasi Potensi Hazard Bahan Pangan Sebagai Upaya Pencegahan Keracunan Jajanan Anak Sekolah
}

\author{
Potential Hazard Identification Training \\ for Poisoning Snacks Prevention
}

\author{
Anna Rakhmawati*, Siti Umniyatie, Evy Yulianti
}

Jurusan Pendidikan Biologi, FMIPA, UNY, *Email: anna_rakhmawati@uny.ac.id

\begin{abstract}
Abstrak
Kasus keracunan karena mengkonsumsi jajanan anak sekolah masih banyak dijumpai di tingkat sekolah dasar. Target pelaksanaan Program Pengabdian kepada Masyarakat yaitu terjadinya peningkatan pengetahuan dan keterampilan guru dan karyawan SD Muhammadiyah Sleman dalam mengenali dan mengidentifikasi potensi hazard (cemaran) bahan pangan; meningkatkan keterampilan dalam memilih bahan pangan yang aman pada jajanan anak sekolah. Kemudian mendampingi dan memotivasi kader guru untuk mengimplementasikan bekal pengetahuan dan keterampilan yang sudah diperoleh dalam mencegah keracunan jajanan anak sehingga jajanan yang dikonsumsi bergizi seimbang, sehat dan higienis. Tahap persiapan meliputi audiensi, koordinasi, dan pemantapan program dengan mitra kemudian identifikasi peserta kegiatan. Tahap pelaksanaan yaitu kegiatan seminar berupa pemberian materi dan pelatihan. Materi disampaikan oleh tim pengabdi dilanjutkan pelatihan keterampilan mengkarakterisasi potensi cemaran baik fisik, kemis maupun biologis pada jajanan anak serta upaya pencegahannya. Kegiatan terakhir yaitu evaluasi dan perbaikan. Hasil program menunjukkan keberhasilan proses yang ditunjukkan dengan kehadiran peserta mencapai $100 \%$, peningkatan hasil tes pengetahuan sebesar $20,47 \%$, dan sebanyak $90 \%$ peserta telah memiliki keterampilan dalam memilih bahan pangan yang aman pada jajanan anak sekolah.
\end{abstract}

Kata kunci: pelatihan, potensi hazard, keracunan

\begin{abstract}
Cases of poisoning after eating snacks still prevalent at the elementary school level. This community development program aims to increase the knowledge, skill of SD Muhammadiyah Sleman teachers and employees in recognizing and identifying potential hazards (contaminants) in food; improving skills in choosing food that was safe on school children snacks. Then accompaning and motivating the cadres of teachers to implement the knowledge and skills was already acquired in preventing poisoning of children so snacks had been consumed nutritionally balanced, healthy and hygienic.First, it started with hearings, coordination, and consolidation of programs with partners then to identify the participants. Second step is held seminar and training the material was presented by a team of devotees continued to characterize potential contamination skills training. The final activity is the evaluation and improvement. The results showed that this program has been succes in reaching the targets, revealing the participant attendance (100\%), an increase of knowledge test $(20,47 \%)$, participant ability to choose safe snacks (90\% participant).
\end{abstract}

Keywords: training, potential hazard, poisoning

\section{PENDAHULUAN}

Data tahun 2012 menunjukkan dari 84 kasus keracunan pangan sebanyak $27,4 \%$ terjadi di sekolah. Selain sekolah, tempat lain yang kerap terjadi keracunan makanan adalah tempat tinggal dan pabrik. Dari kasus keracunan tersebut sebanyak $43 \%$ diakibatkan mikroba dan $17 \%$ disebabkan bahan kimia. Jenis pangan yang menjadi penyebab kasus-kasus itu paling tinggi adalah jajanan sekolah dan masakan rumah 
tangga masing-masing mencakup 27\%. Ketersediaan jajanan sehat di sekolah masih sulit terwujud karena $73 \%$ kasus keracunan pangan di sekolah terjadi di tingkat SD. Kasus tertinggi selanjutnya terjadi di SMP (14\%); perguruan tinggi (9\%), dan SMA (5\%). Salah satu upaya menciptakan jajanan sehat adalah menekan peredaran pangan yang mengandung mikroba dan bahan pangan kimia berbahaya langsung dari sumbernya. Bahan kimia berbahaya yang terpantau adalah rhodamin, formalin, metanil, dan boraks (KOMPAS, 24 Agustus 2013). Kurun waktu Oktober - Desember 2015, terdapat 34 insiden keracunan terdokumentasi oleh SIKERNas yang diberitakan sedikitnya 15 media massa online dari 138 media massa online sebagai sumber berita. Dari 34 insiden keracunan, sebagian besar insiden keracunan didominasi oleh keracunan pangan yaitu sebanyak 26 insiden (20 makanan, 6 minuman), kemudian 4 insiden disebabkan racun alam, 3 insiden disebabkan oleh pencemar lingkungan dan 1 insiden disebabkan oleh suplemen makanan (BPOM, 1 Maret 2016)

Penyebab utama keracunan antara lain mikroba, bahan kimia (formalin, rhodamin B), dan benda asing (fisik) seperti kuku, rambut, staples yang masuk dalam makanan dan peralatannya. Karena anak juga menghabiskan banyak waktu di sekolah, maka kantin sekolah menjadi sasaran utama program BPOM. Program Aksi Nasional Pangan Jajanan Anak Sekolah (PJAS) pernah digalakkan pada tahun 2012. PJAS yang digagas BPOM tidak hanya berfokus pada penyediaan dan perbaikan fasilitas fisik saja, namun juga kebiasaan dan perilaku. BPOM menganjurkan setiap sekolah memiliki manajemen keamanan pangan sekolah secara mandiri dan menguji apakah makanan di kantin sekolah sudah terbebas dari zat kimia berbahaya seperti pengawet, pewarna tekstil dan sebagainya. Untuk meningkatkan minat pembenahan kantin sekolah, juga ada pemberian piagam bintang bagi sekolah dengan kantin yang memenuhi syarat. Padahal rendahnya kualitas PJAS dapat memperburuk status gizi anak sekolah akibat terganggunya asupan gizi. Namun bukan cuma kantin, warung jajanan di sekitar lingkungan sekolah juga patut diawasi. Usaha preventif dan promotif lebih baik dilakukan, karena lebih mahal mengobati daripada mencegah (IZN - pdpersi.co.id, 11 Agustus 2012).

Program Aksi Nasional Pangan Jajanan Anak Sekolah (PJAS) pernah digalakkan pada tahun 2012 tetapi sampai saat ini masih ditemukan kasus-kasus keracunan yang menimpa anak sekolah. Kasus keracunan makanan di lingkungan SD, setiap tahunnya, tertinggi dibandingkan jenjang pendidikan lainnya (JPNN.com, 12 Agustus 2012). Salah satu contoh kasus cemaran mikroorganisme pada jajanan anak yaitu bakteri Escherichia coli ditemukan pada es balok yang dijual di beberapa sekolah di Jakarta. Es balok sebenarnya dibuat untuk mengawetkan ikan dan air yang dipakai tidak dimasak. Es menempati urutan pertama sebagai pangan paling berbahaya dengan jumlah yang tidak memenuhi syarat kesehatan mencapai 58,24\%. Sampel sebanyak 534 yang diambil menunjukkan 311 sampel mengandung bakteri termasuk koliform dan E.coli. BPOM telah mengambil 144 sampel untuk pengujian E.coli dan 13 sampel positif. Hal ini menunjukkan es balok telah tercemar tinja. Cemaran tinja dapat terjadi pada air yang digunakan untuk membuat es balok atau berpindah dari tempat lain pada saat distribusi es balok. Saat pendistribusian umumnya es balok dibawa secara terbuka menggunakan sepeda kayuh, sepeda motor, dan mobil bak terbuka. Produk lain yang berbahaya adalah minuman berwarna dan sirup 48,03\%; jeli atau agar-agar 35,08\%; bakso 32,83\%; kudapan 32,83\%; makanan ringan 12,89\%; dan mie $10,72 \%$. Penyebabnya adalah pewarna yang tidak food grade, bahkan sering kali digunakan pewarna dan pengawet makanan dari bahan berbahaya seperti formalin (Kompas, 10 Oktober 2013)

Upaya pemerintah untuk mencegah kasus keracunan makanan sebenarnya sudah 
sering dilakukan. Badan Pengawas Obat dan Makanan (Badan POM) telah menyampaikan ribuan rekomendasi hasil temuan pengawasan produk obat dan makanan kepada pemerintah daerah belum ditindaklanjuti. Tahun 2015 Badan POM telah melakukan pengawasan sarana distribusi, sarana produksi, pengujian produk pangan, pengawasan label, dan iklan produk pangan yang tidak memenuhi ketentuan menghasilkan 4.145 rekomendasi bagi pemda. Namun hanya $10,52 \%$ yang dijalankan pemda (Kompas, 1 Maret 2016).

Namun demikian masih saja ditemukan kasus-kasus keracunan jajanan anak sekolah di daerah, termasuk di wilayah Kabupaten Sleman DIY. Konsumsi jajanan anak yaitu waktu atau setelah jam sekolah berlangsung sehingga menyebabkan keracunan terjadi hampir setiap tahun. Sedikitnya 27 siswa SD Negeri Krajan 1, Sidoluhur, Godean, Kabupaten Sleman, DIY, keracunan setelah mengonsumsi permen yang dijajakan di lingkungan sekolah (okezone.com, 6 September 2013). Setidaknya 25 murid SD Negeri Sleman 5 mengalami keracunan massal setelah menyantap jajanan es buah saat istirahat sekolah (Tribunjogja, 3 November 2015). Siswa SD Kanisius Kalasan Sleman sebanyak 21 anak mengalami gejala keracunan setelah mengkonsumsi minuman kemasan (Tribunjogja, 14 November 2015). Sembilan belas siswa Sekolah Dasar (SD) Negeri Cibuk Lor, Seyegan, Sleman diduga mengalami keracunan jajanan cumi goreng bersaus yang dibeli di penjual keliling saat istirahat sekolah (Tribunjogja, 30 Januari 2016). Puluhan siswa SMP di Gamping Sleman keracunan makanan yang dikonsumsi sehingga dibawa ke RS (Tribunjogja, 12 Februari 2016).

SD Muhammadiyah Sleman merupakan salah satu sekolah dasar yang terletak di Jalan Kenari, Srimulyo, Triharjo, Kabupaten Sleman, Daerah Istimewa Yogyakarta. Dalam rangka pencapaian visi sekolah yaitu "terwujudnya sekolah unggulan yang dapat mengembangkan potensi peserta didik menuju generasi yang taqwa, cerdas, terampil, berakhlak mulia, dan mampu berkompetisi di era global" maka sekolah ini menyediakan sarana dan prasarana yang memadai. Salah satu sarana yang disediakan yaitu layanan katering makan siang dan kantin. Proses pembelajaran di sekolah berlangsung pukul $6.40 \quad-13.45$ WIB diselingi 2 kali istirahat. Lokasi sekolah berada di tengah perkampungan dan dekat sekitar $50 \mathrm{~m}$ dengan Pasar Sleman menyebabkan mudah ditemukan berbagai penjual jajanan anak. Hal ini menyebabkan siswa banyak yang jajan di sekitar sekolah terutama setelah jam pulang sekolah. Jumlah keseluruhan siswa dari kelas 1 sampai 6 mencapai sekitar 680 anak. Jumlah guru yang mengajar yaitu 30 orang ditambah 6 karyawan. Kegiatan lain yang dilakukan dalam rangka menjalin silaturahmi dan kesinambungan antara pihak sekolah dan orang tua makan diadakan pertemuan rutin dengan seluruh wali murid setiap 2 bulan. Guru dan kepala sekolah merupakan pemegang amanah orang tua ketika anak berada di sekolah untuk mengoptimalkan potensi tumbuh kembangnya. Kontribusi sekolah dengan kolaborasi orang tua memegang peranan penting dalam pengentasan masalah nutrisi pada anak dan upaya pencegahan keracunan jajanan anak. Bertitik tolak dari latar belakang diatas, tim pengabdi yang terdiri atas tim dosen FMIPA UNY bermaksud mengadakan program Pengabdian Kepada Masyarakat bekerjasama dengan guru dan karyawan SD Muhammadiyah Sleman dengan mengangkat topik Pelatihan Identifikasi Potensi Hazard Bahan Pangan sebagai Upaya Pencegahan Keracunan Jajanan Anak Sekolah.

\section{SOLUSI/TEKNOLOGI}

Solusi dan teknologi yang digunakan oleh Tim dalam mengatasi persoalan tersebut meliputi sebagai berikut.

1. Persiapan yaitu audiensi, koordinasi, dan pemantapan program dengan mitra kemudian identifikasi peserta kegiatan 
yaitu guru dan karyawan SD Muhammadiyah Sleman.

2. Pelaksanaan yaitu kegiatan seminar berupa pemberian materi dari tim pengabdi potensi hazard bahan pangan dalam jajanan anak sekolah.

3. Pelatihan keterampilan mengkarakterisasi potensi cemaran baik fisik, kemis maupun biologis pada jajanan anak sekolah dan upaya pencegahannya.

4. Evaluasi dan perbaikan

Evaluasi kegiatan dilakukan berdasarkan aktivitas, peningkatan pengetahuan, keterampilan dan kreativitas serta evaluasi kemanfaatan para peserta selama mengikuti workshop.

a. Pengetahuan awal para peserta terlebih dahulu diobservasi dengan cara melakukan pretest. Soal pretest berkaitan dengan potensi hazard bahan pangan dalam jajanan anak sekolah. Setelah pemberian materi kemudian dilakukan postest.

b. Evaluasi keterampilan peserta dalam mengkarakterisasi potensi cemaran baik fisik, kemis maupun biologis pada jajanan anak dan upaya pencegahannya.

c. Evaluasi Kemanfaatan dilakukan dengan meminta tanggapan/pendapat dari para peserta.

\section{HASIL DAN DISKUSI}

Pelaksanaan kegiatan meliputi berbagai tahap yaitu tahap persiapan; seminar (ceramah dan tanya jawab); pelatihan identifikasi potensi hazard bahan pangan. Persiapan kegiatan dilakukan Hari Jumat tanggal 12 dan 19 Agustus berupa perkenalan tim pengabdi, sosialisasi kegiatan dan koordinasi dengan mitra (Kepala sekolah SD Muhammadiyah Sleman) terkait penentuan peserta pelatihan, waktu, dan tempat pelaksanaan. Target peserta 40 orang yaitu guru dan karyawan SD Muhammadiyah Sleman dengan tempat kegiatan di SD Muhammadiyah Sleman hari
Jumat ketika pertemuan rutin guru dan karyawan sekolah.

Kegiatan pertama yaitu seminar dilakukan pada hari Jumat, 26 Agustus 2016 bertempat di ruang kelas SD Muhammadiyah Sleman peserta yang hadir melebihi target awal yaitu 45 orang terdiri dari guru dan karyawan SD Muhammadiyah Sleman. Seminar dimulai dengan ceramah dan tanya jawab oleh tim pengabdi.Sebelum dan sesudah menerima materi dari tim pengabdi diadakan pretest dan postest bagi peserta seminar. Nilai rata-rata pretest yaitu 5,47 sedangkan postest 6,59 yaitu menunjukkan peningkatan 20,47 \% dibandingkan pretest. Angket diberikan ke peserta pada akhir kegiatan pelatihan untuk menjaring kepuasan peserta dari berbagai segi dengan kriteria kurang, cukup, baik, dan sangat baik. Rata-rata tertinggi yaitu 3,62 (kriteria baik) pada hasil pengabdian dapat dimanfaatkan oleh masyarakat. Ratarata terendah adalah 2,87 (kriteria cukup) pada kesesuaian waktu pelaksanaan dengan kegiatan masyarakat.

Tahap selanjutnya yaitu pendampingan dan monitoring implementasi, tim dosen pengabdi berkunjung ke sekolah setelah dilaksanakan kegiatan PPM. Awalnya, tim dosen melakukan observasi berdasar kriteria jajanan sehat seperti aspek sanitasi dan higiene kantin yang penting dalam proses penyiapan menu serta aspek keamanan pangan yang menjamin bukan hanya makanan bergizi dan sehat untuk anak didik namun juga aman untuk dikonsumsi. Tim pengabdi juga berkesempatan bertemu dengan perwakilan orang tua dan berdiskusi tentang pengembangan penyediaan makanan di sekolah. Selanjutnya, tim dosen memberikan masukan secara langsung kepada sekolah tentang perbaikan penyediaan catering dan kantin dari aspek sanitasi dan higiene serta masukan terhadap. Tahap pendampingan dilakukan bulan September 2016.

Jumlah peserta yang mengikuti workshop melebihi dari target semula yaitu 40 orang tetapi yang hadir 45 orang pada saat kegiatan. Hal ini menunjukkan 
antusiasme para guru dan karyawan karena menganggap bahwa kegiatan ini sangat penting untuk memberikan layanan optimal bagi siswa didik. Tahap awal diisi dengan seminar, pemberian materi oleh tim pengabdi. Materi yang disajikan yaitu Pengenalan Potensi Hazard Bahan Pangan sebagai Upaya Pencegahan Keracunan di Sekolah disampaikan oleh Anna Rakhmawati, M.Si; Siti Umniyatie, M.Si mengemukakan tentang HACCP sebagai Upaya Pencegahan Keracunan Pangan pada Jajanan Anak; sedangkan Evy Yulianti, M.Sc menyampaikan mengenai Metabolisme Racun di dalam Tubuh. Antusiasme peserta pelatihan cukup tinggi terlihat dari banyaknya pertanyaan yang diungkapkan selama sesi tanya jawab. Pertanyaan yang muncul misalnya : cara konsumsi antibiotik apabila telah mengalami sakit akibat kontaminasi jajan anak, dampak anak gemar mengkonsumsi mie instan, pencegahan sakit dengan jamu, dan lainlain. Semua pertanyaan peserta dapat ditanggapi oleh tim pengabdi.

Evaluasi kegiatan dilakukan berdasarkan aktivitas, peningkatan pengetahuan, keterampilan dan kreativitas para peserta selama mengikuti pelatihan identifikasi potensi hazard . Pengetahuan awal para peserta terlebih dahulu diobservasi dengan cara melakukan pretest. Soal pretest berkaitan dengan kasus keracunan jajanan anak, HACCP, keberadaan bahan hazard pada jajanan anak, cara pencegahan kontaminasi pada jajanan anak, aspek sanitasi dan higienitas penyiapan makanan serta racun dalam tubuh. Gambar 1 menunjukkan hasil nilai rata-rata pretest peserta 5,47 menunjukkan pengetahuan awal peserta masih rendah. Setelah pemberian materi kemudian dilakukan postest. Gambar 1 menunjukkan adanya peningkatan nilai postest menjadi 6,59. Meningkatnya pengetahuan peserta sebesar 20,47\% dilihat dari kenaikan rerata skor posttest dibandingkan pretest menunjukkan bahwa peserta telah memahami pemberian materi oleh tim dosen pengabdi sebagai narasumber seminar. Hal ini merupakan salah satu indikator peningkatan pengetahuan dan keterampilan peserta pelatihan mengenai hal-hal yang berkaitan dengan identifikasi potensi hazard jajanan anak sekolah. Pemberian doorprize diberikan kepada 5 peserta yang memiliki peningkatan nilai tertinggi dan diberikan di akhir kegiatan pelatihan.

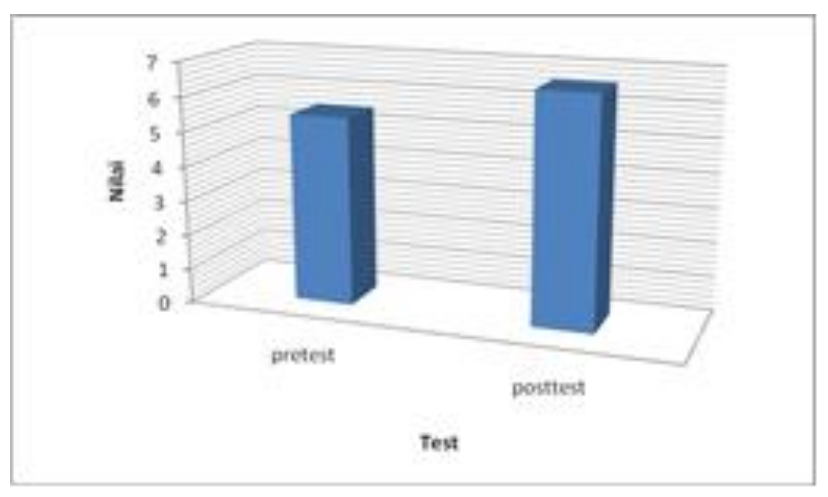

Gambar 1. Rata-rata Nilai Pretest dan Postest

Tahap selanjutnya yaitu pelatihan potensi hazard pada bahan jajanan anak sekolah dengan sampel kue moci, kue nastar, tempe, kacang merah, beras, ikan asin, gethuk, kacang telur, kacang tanah, kerupuk, kerang, jeruk, dan tomat. Peserta pelatihan diberi bahan-bahan pangan tersebut yang telah tercemar fisik, kemis, maupun biologis. Selanjutnya diminta menentukan potensi hazard, sumber potensi hazard, dan upaya pencegahannya. Evaluasi dilakukan berdasarkan pengisian lembar kerja oleh para peserta pelatihan. Hasil evaluasi pelatihan menunjukkan $90 \%$ peserta pelatihan telah dapat melakukan identifikasi dan sumber potensi hazard pada bahan pangan serta upaya pencegahannya. Peserta mampu menentukan potensi hazard baik biologis, kemis, maupun fisik. Sumber potensi hazard dapat berasal dari udara, air, proses pembuatan, distribusi pengolahan, dan lain-lain. Upaya pencegahan misalnya dengan pemilihan bahan dasar yang baik misalnya bebas boraks dan pewarna buatan, proses pemasakan yang benar dengan memperhatikan aspek sanitasi dan higienitas, pengemasan yang baik (misalnya tidak menggunakan staples untuk perekat 
kemasan), penyimpanan suhu dingin, jangan disimpan di tempat lembab, wadah penyimpanan yang kedap udara, memperhatikan kemasan dan tanggal kadaluarsa jajanan anak, membuat sendiri jajanan yang dikonsumsi oleh anak didik, dan lain-lain.

Tabel 1. Rata-rata skor kepuasan peserta pelatihan

\begin{tabular}{clc}
\hline No & \multicolumn{1}{c}{ Pernyataan } & Skor \\
\hline 1 & $\begin{array}{l}\text { Kesesuaian kegiatan } \\
\text { pengabdian dengan kebutuhan } \\
\text { masyarakat }\end{array}$ & 3,28 \\
\hline 2 & $\begin{array}{l}\text { Kerjasama pengabdi dengan } \\
\text { masyarakat }\end{array}$ & 3,21 \\
\hline 3 & $\begin{array}{l}\text { Memunculkan aspek } \\
\text { pemberdayaan masyarakat }\end{array}$ & 3,05 \\
\hline 4 & $\begin{array}{l}\text { Meningkatkan motivasi } \\
\text { masyarakat untuk } \\
\text { berkembang }\end{array}$ & 3,33 \\
\hline 5 & $\begin{array}{l}\text { Sikap/perilaku pengabdi di } \\
\text { lokasi pengabdian }\end{array}$ & 3,41 \\
\hline 6 & $\begin{array}{l}\text { Komunikasi/koordinasi } \\
\text { dengan penanggung jawab } \\
\text { lokasi pengabdian }\end{array}$ & 3,28 \\
\hline 7 & $\begin{array}{l}\text { Kesesuaian waktu } \\
\text { pelaksanaan dengan kegiatan } \\
\text { masyarakat }\end{array}$ & 2,87 \\
\hline 8 & $\begin{array}{l}\text { Kesesuaian keahlian pengabdi } \\
\text { dengan kegiatan pengabdian }\end{array}$ & 3,46 \\
\hline 9 & $\begin{array}{l}\text { Kemampuan mendorong } \\
\text { kemandirian/swadaya } \\
\text { masyarakat }\end{array}$ & 3,00 \\
\hline 10 & $\begin{array}{l}\text { Hasil pengabdian dapat } \\
\text { dimanfaatkan masyarakat }\end{array}$ & 3,62 \\
\hline &
\end{tabular}

Keterangan makna skor 1=kurang; 2=cukup; 3=baik; 4=sangat baik.

Evaluasi kemanfaatan dilakukan dengan meminta tanggapan/pendapat dari para guru dan karyawan SD Muhammadiyah yang menjadi peserta pelatihan. Kepuasan peserta pelaksanaan kegiatan PPM dapat diketahui dari hasil instrumen kepuasan pelanggan yang diisi oleh para peserta. Tabel 1 menggambarkan hasil penjaringan kepuasan peserta. Semua pernyataan rata-rata skor diatas 3 adalah baik, kecuali untuk kesesuaian waktu pelaksanaan dengan kegiatan masyarakat kriteria cukup $(2,87)$. Kesesuaian waktu sudah diantisipasi dengan koordinasi mitra yaitu pihak kepala sekolah dan wakil kurikulum yaitu pelaksanaan di hari Jumat saat pertemuan rutin guru dan karyawan. Pelaksanaan kegiatan juga dilakukan dengan memperhatikan kalender akademik sekolah dengan harapan tidak berbenturan dengan jadwal penerimaan siswa baru, ujian sekolah, pelatihan guru dan karyawan oleh dinas, jadwal libur, dan sebagainya. Namun ternyata juga masih ada kendala lain. Hal ini memang tidak bisa dipungkiri mengingat mitra kegiatan adalah guru yang memiliki keharusan jam mengajar. Kegiatan dilakukan bulan Agustus bersamaan dengan kegiatan Kegiatan Belajar Mengajar sudah aktif setelah libur lebaran sehingga jadwal sekolah sudah padat.

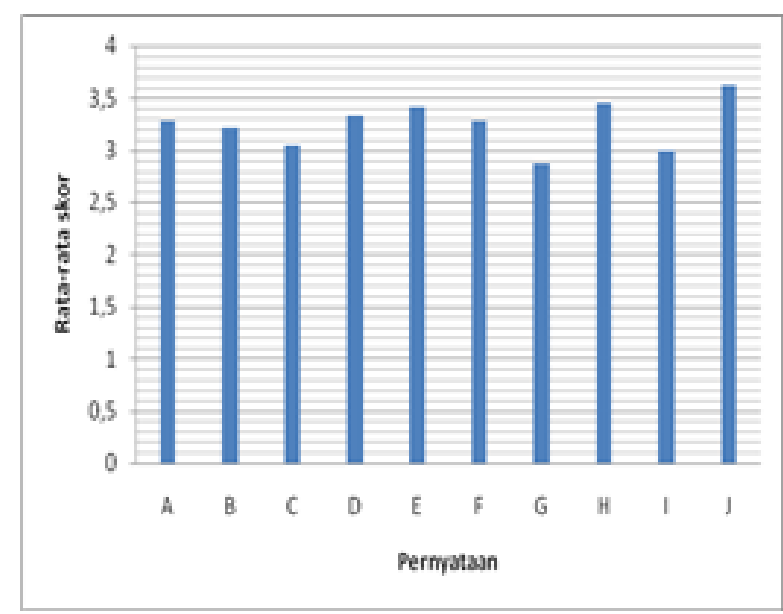

Gambar 2. Angket peserta tentang pelaksanaan kegiatan PPM.

Keterangan gambar

A : Kesesuaian kegiatan pengabdian dengan kebutuhan masyarakat

B : Kerjasama pengabdi dengan masyarakat

C : Memunculkan aspek pemberdayaan masyarakat

D : Meningkatkan motivasi masyarakat untuk berkembang

E : Sikap/perilaku pengabdi di lokasi pengabdian

F : Komunikasi/koordinasi dengan penanggung jawab lokasi pengabdian

$\mathrm{G}$ : Kesesuaian waktu pelaksanaan 
dengan kegiatan masyarakat

$$
\begin{aligned}
\mathrm{H}: & \begin{array}{l}
\text { Kesesuaian keahlian pengabdi } \\
\text { dengan kegiatan pengabdian }
\end{array} \\
\mathrm{I}: & \begin{array}{l}
\text { Kemampuan mendorong } \\
\text { kemandirian/swadaya masyarakat }
\end{array} \\
\mathrm{J} \quad: & \begin{array}{l}
\text { Hasil pengabdian dapat dimanfaatkan } \\
\text { masyarakat }
\end{array}
\end{aligned}
$$

Hasil angket secara keseluruhan menunjukkan hasil diatas 3. Hal ini mengindikasikan bahwa kegiatan pelatihan ini baik bagi guru dan karyawan SD Muhammadiyah Sleman. Gambar 2 menunjukkan aspek hasil pengabdian dapat dimanfaatkan masyarakat menduduki peringkat tertinggi $(3,62)$; diikuti kesesuaian keahlian pengabdi dengan kegiatan pengabdian $(3,46)$; dan sikap/perilaku pengabdi di lokasi pengabdian $(3,41)$. Pernyataan peserta pelatihan berupa komentar, saran ataupun masukan bagi pelaksanaan pengabdian memandang positif. Misalnya lebih dikembangkan ke masyarakat luas, sudah bagus dan perlu lebih sering diadakan, perlunya pendampingan lebih lanjut, dapat berkolaborasi dengan Badan POM, informasinya cukup bagus dan dapat digunakan untuk tambahan bahan mengajar, dan lain-lain.

Tahap selanjutnya yaitu pendampingan ke sekolah hasil observasi kemudian didiskusikan dengan pihak sekolah, catering, dan kantin sehingga sekolah dapat membantu penyedia catering dan kantin untuk mengatasi permasalahan tersebut dan melakukan perbaikan.

\section{KESIMPULAN}

Berdasarkan uraian hasil dan diskusi maka dapat di simpulkan sebagai berikut :

1. Pengetahuan guru dan karyawan SD Muhammadiyah Sleman meningkat $20,47 \%$ dalam mengenali dan mengidentifikasi potensi (hazard) cemaran bahan pangan

2. Sembilan puluh persen guru dan karyawan SD Muhammadiyah Sleman memiliki ketrampilan dalam memilih bahan pangan yang aman pada jajanan anak sekolah

3. Guru dan karyawan SD Muhammadiyah Sleman mampu mengimplementasikan bekal pengetahuan dan keterampilan yang sudah diperoleh melalui program pengabdian ini dalam mencegah keracunan jajanan anak sehingga jajanan yang dikonsumsi bergizi seimbang, sehat dan higienis bagi anak-anak SD Muhammadiyah Sleman sekaligus membantu mensosialisasikannya pada orang tua dan masyarakat

Saran yang dapat diterapkan untuk kegiatan pelatihan selanjutnya sebagai berikut:

1. Kegiatan pengabdian yang berkaitan dengan peserta didik perlu diperluas aspeknya tidak hanya jajanan anak sekolah tetapi aspek lain misalnya olahraga, pola asuh, dan lain-lain.

2. Orang tua atau wali anak perlu dilibatkan lebih banyak dalam kegiatan pelatihan.

\section{UCAPAN TERIMA KASIH}

Ucapan terima kasih kami haturkan kepada SD Muhammadiyah Sleman dan Dekan FMIPA UNY yang telah memberi dana kegiatan PkM.

\section{PUSTAKA}

Anonim. 2012. Enam puluh persen Kasus Keracunan di Sekolah Dipicu Buruknya Kebersihan. JPNN.com diakses tanggal 4 Maret 2016 pukul 13.30 WIB.

2012. Anak-anak, Korban Keracunan Paling Banyak. IZN pdpersi.co.id, 11 Agustus 2012 diakses tanggal 4 Maret 2016 pukul $10.30 \mathrm{WIB}$

2013. Keracunan Pangan di Sekolah Tertinggi. Kompas 24 Agustus 2013

2013. Ditemukan Bakteri E.coli pada Es Balok. Kompas 10 Oktober 2013 
2013. Makan Permen, 27 Murid SD di Sleman Keracunan . okezone.com diakses tanggal 4 Maret 2016 pukul 12.30 WIB 2015. Dinkes Sleman Lakukan Penyelidikan Kasus Keracunan Massal Es Buah. tribunjogja.com 3 November 2015

2015. Dinkes Sleman Kaji Penyebab Keracunan Massal di SD Kanisius Kalasan tribunjogja.com 14 November 2015 - 2016. Belasan Siswa SD Keracunan Cumi Goreng Saus. tribunjogja.com 30 Januari 2016 . 2016. Puluhan Siswa Keracunan Makanan di Gamping. tribunjogja.com 12 Februari 2016 2016. Rekomendasi tidak ditindaklanjuti. Kompas 1 Maret 2016 Anni Kusumaningsih. 2010. Beberapa Bakteri Patogenik Penyebab Foodborne Disease pada Bahan Pangan Asal Ternak. Prosiding Balai Penelitian Veteriner Ternak. Bogor

Badan POM. 2016. Berita Keracunan Bulan Oktober - Desember 2015. http://www.bpom.com diakses tanggal 4 Maret 2016 pukul 11.30 WIB

Caldwell, J. G. 2009. Harmful Food Additives. Diakses dari http://www.foundationwebsite.org diakses tanggal 1 Juli 2013 pkl 20.20 WIB

Kent, L.T. 2010. Food Additives Side Effect. Diakses dari http://www.livestrong.com/article/1294 93-additive-side-effects/ diakses tanggal 10 Juli 2015 pkl 13.21 WIB

Nindita, L.O and A.K. Wardani. 2013. Purifikasi Phage Cocktail Serta Spektrum Penghambatannya terhadap Bakteri penyebab Foodborne Disease. Jurnal Teknologi Pertanian Vol. 14 No. 1 [April 2013] 47-56

Natural Health Information. 2007. Food Additives. Diakses dari http://www.natural-health-informationcentre.com/food-additives.html diakses tanggal 10 Juli 2015 pkl 14.20 WIB

Utami, A. 1996. Kontaminasi Bakteri E. coli pada Peralatan Makanan Di Beberapa Penjual Makanan Dan Minuman Di Kampus UI Depok, Skripsi, Fakultas Kesehatan Universitas Indon 